\title{
MATHEMATICAL MODELLING OF VORTEX GENERATION PROCESS IN THE FLOWING PART OF THE VORTEX FLOWMETER AND SELECTION OF AN OPTIMAL TURBULENCE MODEL
}

\author{
A.L. Kartashev, South Ural State University, Chelyabinsk, Russian Federation, \\ al kartashev@mail.ru, \\ A.A. Krivonogov, South Ural State University, Chelyabinsk, Russian Federation, \\ alexeykrivonogov@mail.ru
}

The article is devoted to mathematical modelling of processes, occurring in the flowing part of the vortex flowmeter, by the finite element method. The urgency of the current study is due to the lack of research in this area.

The analysis of research literature devoted to the study of non-stationary vortex shedding processes and other hydrogasdynamics effects occurring in the flowing part of the vortex flowmeter and similar devices has been performed. A brief description of the vortex generation process behind the bluff body placed in a circular cross-section pipe as well as the basic criteria for functional products are presented.

Various mathematical models for describing turbulent flows in pipes with an object or obstruction were investigated. The available software packages suitable for modelling unsteady turbulent flows were analyzed.

The ANSYS software package, in particular CFX module for fluid and gas, as well as various approaches to mathematical modelling were used to simulate the flowing part of the vortex flowmeter. The article provides a brief description of the basic computational domain settings, mesh formation and initial and boundary conditions setting. To verify the numerical calculations, physical experiments on fluid and gas test benches were performed. For this purpose the samples corresponding to the numerical model have been manufactured and tested.

The research findings led us to conclude that in terms of accuracy and calculation time the optimal approach to numerical simulation of vortex generation processes (Karman vortex street) in the vortex flowmeter is the use of the Reynolds-averaged Navier - Stokes equations (or RANS equations) closed by means of a two - equation model of turbulence, known as the $k-\varepsilon$ model, which is confirmed by comparison with the experimental data.

Keywords: mathematical modelling; turbulence model; flowing part; vortex flowmeter; bluff body.

\section{Introduction}

In the modern world liquid and gas flow measurement is important in a variety of industries, such as housing and utilities, oil, food, metals, and others. Customers may have different requirements for flowmeters, but the device's cost, its service life and high metrological performance are always the order of the day. In accordance with the specified requirements, a large number of flowmeters, based on different measurement methods, were developed [1, 2]. However, it is safe to say that among all the flowmeters currently available in the market, vortex flowmeters are the most universal, reliable and relatively cheap.

The flowing part of the vortex flowmeter is a pipeline section, housing a motionless bluff body of a special form (Fig. 1), whose axis is perpendicular to the pipe axis. Viscous liquid 
or gas, flowing around the bluff body, induces coherent eddy structures behind it, regularly shedding from the streamlined body on its two downstream sides. The sensing element (e.g. wing, piezoreceiver, thermal anemometer, fiber optic, microphone, etc.) converts the energy pressure pulse of a regular vortex into the output electrical signal [3]. The vortex formation frequency in a wide range of speeds is proportional to the volumetric flow of a fluid, while the pulses number is proportional to the fluid volume that has passed through the flowmeter.

The flow structure and the laws of regular vortices formation in a wide range of parameters is uniquely determined by two numbers of hydrodynamic similarity: the Strouhal number - Sh (2) and the Reynolds number - Re (1).

The Reynolds number characterizes the ratio of inertial and viscous forces, determined by the relation:

$$
R e=\frac{V_{a v e} \cdot D}{\nu}
$$

where $\nu$ is kinematic viscosity, $D$ is flowing part diameter, $V_{\text {ave }}$ is average flow velocity. The working range of numbers for the flowmeter is from 10000 to 200000.

The Strouhal number is a dimensionless vortex shedding frequency, normalized by the inlet flow velocity and determined by the relation:

$$
S h=\frac{V_{a v e} \cdot d}{f}
$$

where $f$ is vortex generation frequency, $d$ is width of bluff body.

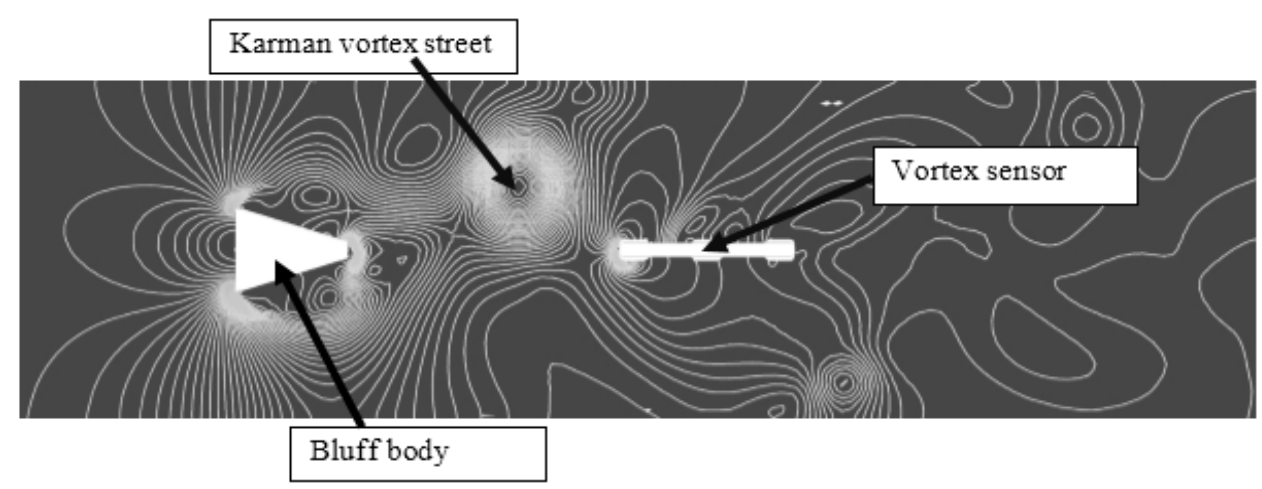

Fig. 1. Flowing part of vortex flowmeter in work process [4]

When creating a vortex flowmeter measurement system, the main problem is to ensure the stability of vortex formation process in a sufficiently wide velocity range. Measuring very low liquid and gas flow rate presents a particular challenge. The solution of these problems depends on how deeply we understand the mechanism of vortex formation and the further spread vortices in downstream flow. A significant amount of data on an orderly vortex formation process behind bluff bodies has been accumulated [5]. It should be noted, however, that many questions still remain open, especially those associated with the influence of various factors on the vortex formation process. Flow boundedness (a bluff body of a vortex flowmeter is located in a flow channel), velocity profile unevenness, free stream turbulence, velocity pulsations in a flow, and the influence of three-dimensional effects during vortex generation on the flowmeter work stability are among these factors. 
Since there is no way of calculating the optimal shape of a flow part, detecting unambiguous analytical and empirical dependencies based on these factors, it becomes necessary to use other methods. The most common method to determine the optimal form of a flowbody is a physical experiment. By successive approximations or by using the experiment planning theory, researchers obtain the optimal variant of the flowtube geometry, but this process requires a lot of time and material costs. Moreover, it is not always possible to set up the experiment properly and to ensure its repeatability. But there is an alternative way, which consists in mathematical modelling of an experiment $[4,6,7]$. Currently, mathematical models are widely applied for simulating various processes, and fluid dynamics is not an exception.

At present, there are relatively new instruments for numerical investigation of hydrodynamics processes that make it possible to clarify some issues in this area. Therefore, the present study relating to the selection of an optimal mathematical algorithm for modelling the vortex shedding from the bluff body and the distribution of vortices in the downstream appears to be very acute. It is necessary to determine the optimal mathematical model for the task from considerations of minimum calculation time and maximum convergence with the experiment.

\section{Analysis of Modern Approaches to Mathematical Modelling of Detachable Periodic Streams}

Liquid and gas flow simulation, commonly known as Computational Fluid Dynamics (CFD), is one of the most challenging areas in numerical simulation. The CFD analysis is based on the Navier - Stokes system of equations [8]. These equations describe the motion of a continuous medium (liquid or gas). The system includes the continuity equation and the equation of motion. The Navier - Stokes equations system can be used under two conditions [9]:

- The medium must be continuous. The Knudsen number $K n=l f / L \ll 1$.

- The generalized rheological Newton's law must be executed.

Currently, there are three CFD approaches to numerical simulation:

DNS - Direct Numericl Simulation. It is the most accurate modelling method of turbulent flows, including autooscillatory ones, but its use requires huge computing resources, so its application for solving applied fluid dynamics problems will be possible not earlier than in $40-50$ years [10].

LES - Large Eddy Simulation. The essence of this method consists in the fact that relatively large eddies whose size is considerably larger than that of mesh cells are calculated without the use of turbulence models, while small-scale turbulence is modeled using the closing relations for small-scale "subgrid" turbulence similar to RANS semi-empirical models [11]. Nevertheless, just as DNS, LES method simulation requires significant computing resources.

RANS - Reynolds Average Navier - Stokes. The main advantage of RANS approach is that it is resource-saving, compared to DNS and LES methods. Therefore, RANS method is of obvious practical interest in calculating complex turbulent flows, such as flows in the flowing part of the vortex flowmeter. 
Reynolds equation system is obtained by averaging the time of unsteady threedimensional Navier - Stokes [12]. Reynolds averaged system is not closed as it integrates Reynolds stress tensor. To determine the turbulent stress tensor the turbulence models are applied.

At present, there are many turbulence models, but a universal model which may simulate all types of turbulent flows has not yet been invented. The following turbulence models are suitable for simulating the vortex flowmeter:

Model with One Differential Equation. The most common type of turbulence models with one equation is Spalart - Allmaras model (SA model) [12]. This model was developed specially for aerospace applications. But later, this model began to be used more widely, for example in turbo machinery. SA model is sufficiently accurate and economical for unseparated flow simulation and flows with not very large separation zones. But this accuracy is not guaranteed for flows with large separation zones, free shear flows, and decaying turbulence.

Models with Two Differential Equations. At present, the most commonly used types of models with two differential equations are $k-\varepsilon$ and $k-\omega$.

For standard $k-\varepsilon$ turbulence models two transport equations are employed: one for the turbulent kinetic energy $k$, another one for the calculation of turbulent kinetic energy dissipation $\varepsilon$ [13]. It should be noted that the $k-\varepsilon$ model is not suitable for calculating the near-wall flow, so in the near-wall cells the wall-functions or Low - Reynolds models are used $[11,14,15]$. Standard $k-\varepsilon$ turbulence models are suitable for most engineering tasks, which have streams with moderate deformation of velocity fields.

There is also a less known version of $k-\varepsilon$ model, for example the model obtained by using the renormalization group theory applied to the Navier - Stokes called RNG $k-\varepsilon$ [16]. Compared to the standard $k-\varepsilon$ version, this model shows an improved compliance between the calculated and experimental data for certain types of flows, in particular at relatively low Reynolds numbers, greater streamlines curvature, and large strain field of velocity.

Nevertheless, $k-\varepsilon$ turbulence models have one serious disadvantage: when calculating flows with a positive (adverse) pressure gradient, all models tend to overestimate the generation of turbulent kinetic energy, which leads to a fundamentally incorrect description of such flows. This disadvantage constitutes a serious obstacle to stream simulations of flow separation from a smooth wall. The use of near-wall functions based on the wall law leads to errors in the calculation of separated flows and flows in complicated geometry domains $[9]$.

It has been found that another type of turbulence models, namely $k-\omega$ type [11], where instead of transport equations the equation for specific dissipation $\omega=\varepsilon / k$ is used, leads to increased compliance with the experiment, if the separation area is not great. The $k-\omega$ model is considered to be more suitable for describing a near-wall flow in boundary layers. However, in free developed turbulent flows, located far away from solid surfaces, the problem of numerical assignment $\omega$ at the boundaries, where the stream enters the calculation domain, arises. As a result, we may conclude that $k-\omega$ model works best near the wall. In this case, there is no need for dense grid resolution $y^{+}=3 . k-\varepsilon$ model is suitable for describing well-developed flows. As a result, SST (Share Stress Transport) turbulence model or Menter Model, combining standard $k-\varepsilon$ and $k-\omega$ models, was created [17-20]. 
Reynolds Stresses Models (RSM). Turbulence models of this type do not use the hypothesis of turbulent viscosity (Boussinesq). Instead, the equation is solved individually for each component of Reynolds stresses $\overline{u_{i}^{\prime} u_{j}^{\prime}}$ and a transfer equation for dissipation velocity of kinetic energy turbulence $\varepsilon[11,15]$. Thus, the application of these models makes it possible to take into account the anisotropy of turbulent fluctuations. As a result, these models may be used for flows with large curvature streamlines, swirling flows, and large deformation of velocity field. Potentially, the RSM turbulence model is more promising than models based on turbulence viscosity.

However, when using turbulence models of this type, the simulations of numerous unclosed correlations, which arise when transport equations are being derived, may have doubtful reliability and validity. In addition, difficulties arise when setting boundary conditions near the solid surface.

There are a lot of turbulence models [21, 22]. The main ones used at the moment are $k-\varepsilon, \mathrm{RNG} k-\varepsilon, \mathrm{SST}$, and RSM.

At present, there are many commercial and free software packages for numerical simulation, which contain these turbulence models. The most excelled is ANSYS software package. Therefore, it was decided to perform numerical calculations in the software package ANSYS, in particular CFX module, because this software application allows us to simulate this kind of tproblems.

\section{Model Description}

Flow part of vortex flowmeter Rosemount 8600 DN25 (Fig. 3) was chosen as the simulated sample, with some modifications. In the finite element model, the control point located in the sensor place was used instead of vortices sensor. The pressure pulsations were detected at the control point during the calculation process. The test data were subsequently subjected to spectral analysis processing using Fourier transform.

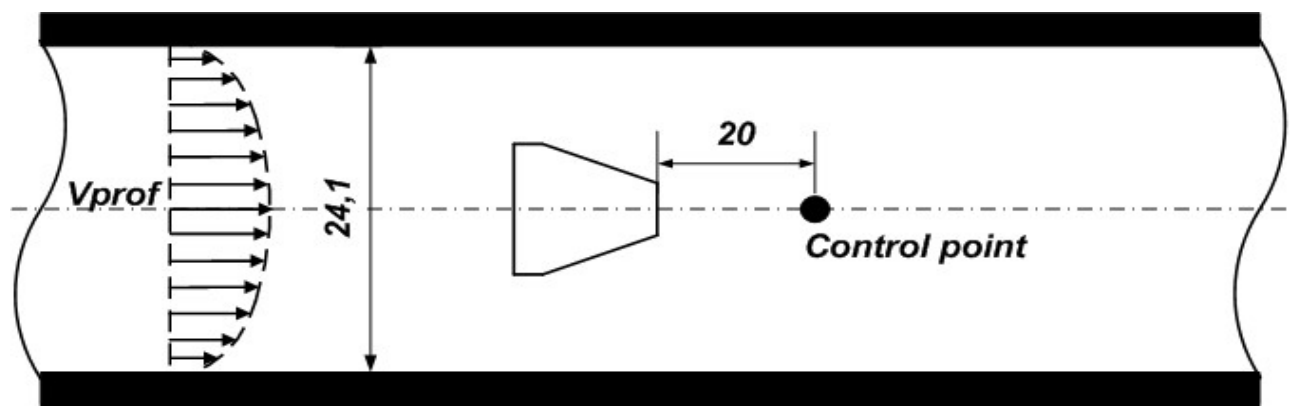

Fig. 2. Flowing part of Rosemount 8600 without sensor element

The finite element model for flow simulations (Fig. 4) was built in ANSYS software package with the help of ICEM CFD mesh generator. The mesh was developed in semiautomatic mode using the O-Grid block method. The use of this meshing method enables the calculation accuracy to be increased and the calculation time reduced.

Based on the turbulence models analysis, the following four models were chosen: $k-\varepsilon$, RNG $k-\varepsilon$, RSM, and SST. The grid for these models had a relatively low density. The grid for the flowing part of the vortex flowmeter consisted of 350 - 500 thousand cells, depending on the turbulence model, because the height of the first near-wall cell varies with different turbulence models. 


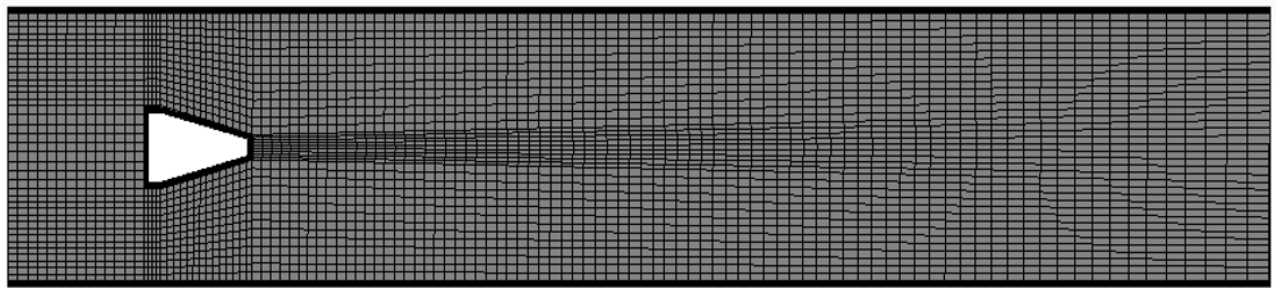

Fig. 3. Finite element model of the vortex flowmeter flow part

The water was set at normal conditions as a working medium flowing in the flow part. Heat transfer in the model was not taken into account. The calculation was performed in non-stationary formulation because the vortex shedding process is autooscillating.

In addition, the initial turbulence velocity profile (3) was set to reduce the computing resources (Fig. 4), thereby reducing the initial pipe section.

$$
V_{\text {prof }}=V_{\text {max }} \cdot\left(1-\frac{r}{R_{\max }}\right)^{0.143}
$$

where $V_{\text {prof }}$ is velocity change along the radius, $r$ is radius variable, $V_{\max }$ is maximum velocity value in pipe.

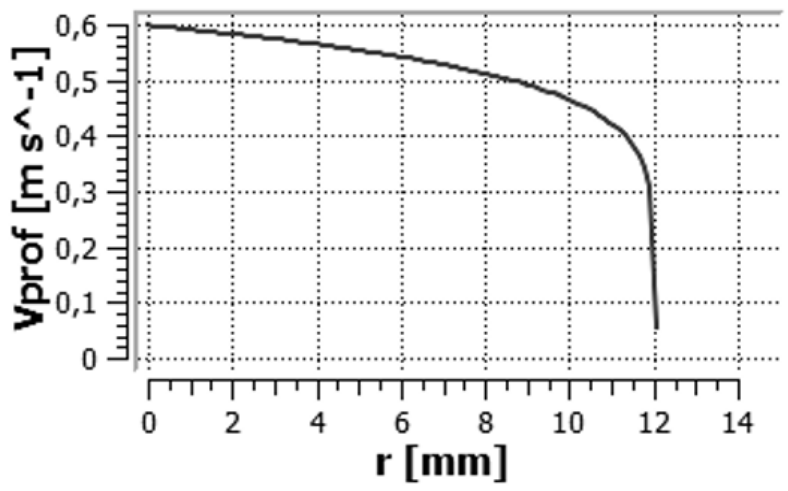

Fig. 4. Initial turbulence velocity profile

To verify the numerical model, the experiments were conducted [4]. Detection of vortex pulsations was carried out through the use of the mechanical sensor «wing ». Tests were performed on a water stand at various flow velocities. The test model conformed to the numerical, except for the presence of the vortex sensor in it.

As a result, more than 16 non-stationary calculations and at least 3 tests, without having to reinstall the flowmeter, were carried out.

In each numerical calculation, at least 6000 iterations and 50 periods of vortices oscillation were computed. This is necessary for the correct spectral analysis.

\section{The Results of Numerical Simulation}

According to the calculations results, the point diagrams (Fig. 5, 6) were built in MS Excel. For clarity, the result points were connected in smooth line, which was built by means of cubic Bezier curves method in MS Excel. 
Fig. 5 shows the processed results of our calculations. The graph shows the reduced error for each curve, calculated by averaging the Strouhal number in range of Reynolds numbers. This diagram shows how a calculated results line matched with the experimental curve.

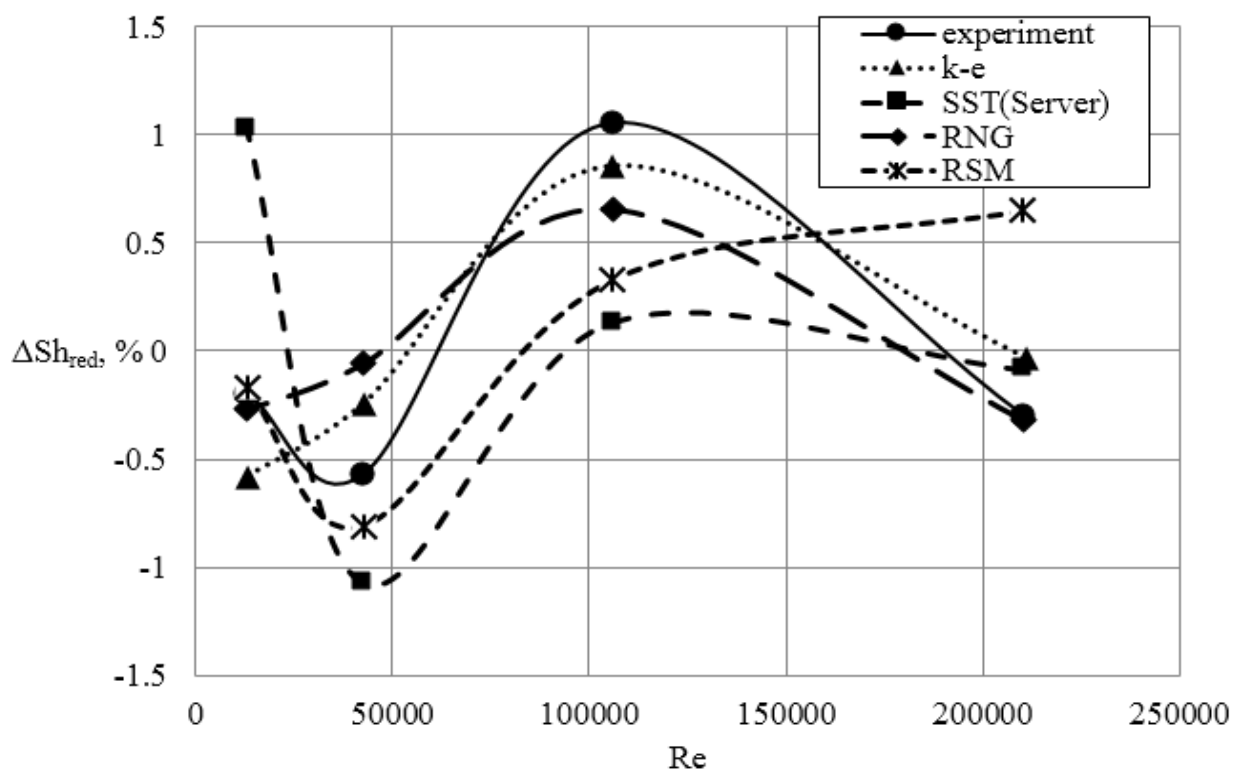

Fig. 5. Strouhal number reduced error

Fig. 6 shows the relative error for each curve with reference to the experimental data. This diagram shows the percentage deviation of the calculated Strouhal number from the experimental one.

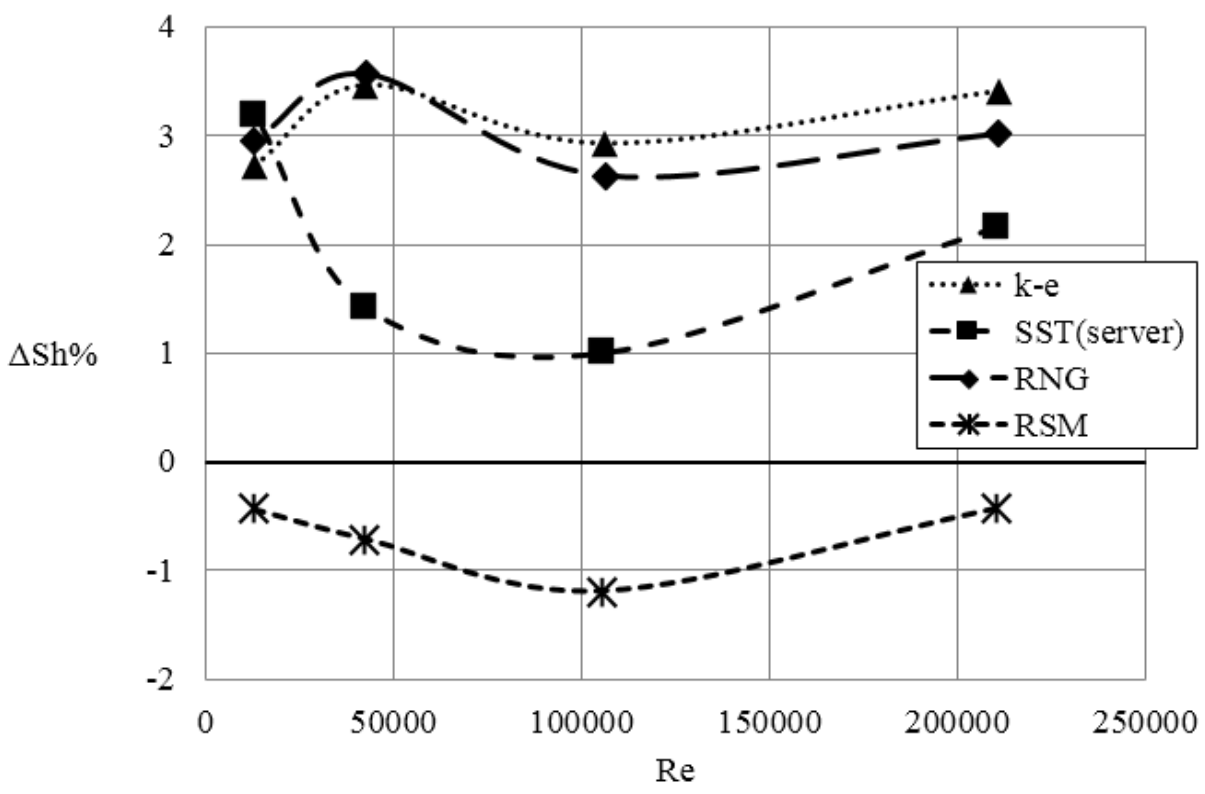

Fig. 6. Strouhal number relative error

Relying on the diagrams analysis results, we may conclude that the $k-\varepsilon$ and RNG $k-\varepsilon$ turbulence models show similar results (Fig. 5) and agree with the experimental data 
quite accurately (the deviation is less than $0,5 \%$ ), but the RNG model shows the result slightly worse, $0,25 \%$ on average, than the default $k-\varepsilon$. Nevertheless, if we look at the relative error values (Fig. 6), it becomes clear that the relative error is large enough, 3\% on average. This effect is due to increase in the turbulent kinetic energy generation, which in turn leads to overestimation of the vortex shedding frequency.

SST turbulence model for reduced error demonstrates greater disagreement than the $k-\varepsilon$ and RNG $k-\varepsilon$, about $2 \%$. On the other hand, SST model agrees better with the experiment, especially if we pay attention to the points corresponding to minimal flow rate of $\operatorname{Re}=13000$. This phenomenon is explained by the fact that the SST model does not use the wall functions in boundary layer unlike $k-\varepsilon$ and RNG $k-\varepsilon$. Also, if we look at the relative error graph, it becomes clear that the SST model is most consistent with the experimental data; the relative error does not exceed $2 \%$ on average.

RSM model shows a high degree of conformity to the experiment. The average deviation for the reduced error does not exceed $0,5 \%$, while the calculated curve coincides with the experiment pretty good. If you look at a relative error graph, it becomes apparent that only this turbulence model has an error with a negative sign that does not exceed $1,2 \%$. This result is explained by the fact that this model uses the Boussinesq turbulent viscosity hypothesis.

It turns out that, in terms of accuracy and results quality, Reynolds stress model surpasses RSM. However, there are other parameters that cannot be ignored, namely the computation time and needed computing resources. Table has been constructed to analyze these parameters, which shows the results of time spent on one time step. Data are presented for Dell T3600 workstation (4 cores, 32 Gb DDR).

Table

Estimation of calculation time per one iteration

\begin{tabular}{|l|c|}
\hline Turbulence model & Calculation time per one iteration, seconds \\
\hline SST & 33,4 \\
\hline$k-\varepsilon$ & 18,0 \\
\hline RNG $k-\varepsilon$ & 19,7 \\
\hline RSM & 76,7 \\
\hline
\end{tabular}

As shown in Table, RSM model is the most resource consuming. Since more equations are solved in this model than in any other, there is a separate equation for each Reynolds stress tensor. Next in order of resource consumption is the SST model; this is due to a denser near-wall mesh in comparison with $k-\varepsilon$ model. RNG $k-\varepsilon$ and $k-\varepsilon$ models show similar time, but RNG $k-\varepsilon$ is a bit slower than $k-\varepsilon$, since the source term in RNG $k-\varepsilon$ is function rather than constant as in a $k-\varepsilon$ model. As a result, based on total estimation of criteria such as time, accuracy, and calculations consistency, we concluded that $k-\varepsilon$ turbulence model is optimal.

\section{Conclusion}

With mathematical modelling of the flow part of vortex flowmeter in ANSYS CFX, the block-structured hexagonal grid and the initial velocity profile must be used. According 
to the calculations results, we may conclude that $k-\varepsilon$ model as it shows high accuracy (Fig. 5) and does not require much calculation time (Table) is the optimal turbulence model. Most likely, this is due to fact that the separation point on a bluff body is strictly defined: this is a sharp edge of the bluff body. From a practical standpoint, the free flow vortex formation process, which is best described by the $k-\varepsilon$ turbulence model, is of prime interest, provided that analysis is carried out only for the vortex generation frequency.

\section{References}

1. Kremlevskiy P.P. Raskhodomery $i$ schetchiki kolichestva [Flowmeters and Counters]. Leningrad, Mashinostroenie, 1989. 701 p.

2. Baker R.C. Flow Measurement Handbook: Industrial Designs, Operating Principles, Performance, and Applications. N.Y., Cambridge University Press, 2000. 524 p. DOI: $10.1017 /$ CBO9780511471100

3. Kremlevskiy P.P. Rashodomery i schetchiki kolichestva veshhestv. Kn. 1 [Flowmeters and Counters of Substances Amount. Vol. 1]. St. Petersburg, Politehnica, 2002. 409 p.

4. Kartashev A.L., Krivonogov A.A. [Research of Spatial Hydrodynamic Effects in the Meterbody of the Vortex Flowmeter]. Bulletin of the South Ural State University. Series: Mechanical Engineering Industry, 2015, vol. 15, no. 4, pp. 5-13. (in Russian) DOI: $10.14529 /$ engin150401

5. Faber T.E. Gidroajerodinamika [Fluid Dynamics for Physicists]. Moscow, Postmarcet, 2001. $560 \mathrm{p}$.

6. Kartashev A.L., Krivonogov A.A. Spatial Hydrodynamic Effects Investigation in the Vortex Flowmeter and Estimation of Numerical Simulation Capability. Nauka JuUrGU. Sekcija tehnicheskih nauk. Materialy 66-j nauchnoj konferencii. [SUSU Science. Section of Technical Sciences. Proceedings of 66th Scientific Conference], 2014, pp. 33-40. (in Russian) Available at: http://dspace.susu.ru/xmlui/bitstream/handle/0001.74/4287/3.pdf

7. Bogdanov V.D., Konyukhov A.V., Krivonogov A.A., Safonov E.V., Dorohov V.A. [Using of Numerical Simulation Methods in the Development of Vortex Flow Meters]. Sensor and Systems, 2012, no. 8 (159), pp. 40-43. (in Russian)

8. Snegiryov A.Yu. Vysokoproizvoditel'nye vychisleniya $v$ tekhnicheskoy fizike. Chislennoe modelirovanie turbulentnykh techeniy [High-Performance Computing in Technical Physics. Numerical Simulation of Turbulent Flows]. St. Petersburg, Polytechnic University, 2009. 143 p. (in Russian)

9. Bailly C., Comete-Bellot G. Turbulence. Springer International Publishing, 2015. 360 p. DOI: $10.1007 / 978-3-319-16160-0$

10. Spalart P.R. Strategies for Turbulence Modelling and Simulations. International Journal of Heat and Fluid Flow, 2000, vol. 21, pp. 252-263. DOI: 10.1016/S0142-727X(00)00007-2

11. Wilcox D.C. Turbulence Modelling for CFD. La Canada, DCW Industries, 1998. 460 p.

12. Spalart P.R., Allmaras S.R. A One-Equation Turbulence Model for Aerodynamic Flows. Technical Report AIAA-92-0439. 30th Aerospace Scinces Meeting and Exibit, 1992. 22 p. DOI: $10.2514 / 6.1992-439$

13. Launder B.E., Spalding D.B. Lectures in Mathematical Models of Turbulence. London, Academic Press, 1972. 169 p.

14. Lapin Ju.V., Strelec M.H. Vnutrennie techenija gazovyh smesej [The Internal Flow of Gas Mixtures]. Moscow, Nauka, 1989. 368 p. 
15. Pope, S.B. Turbulent Flows. Cambridge: Cambridge Univ. Press, 2000. 771 p. DOI: $10.1017 / \mathrm{CBO} 9780511840531$

16. Orszag S.A., Yakhot V., Flannery W.S., Boysan F., Choudhury D., Maruzewski J., Patel B. Renormalization Group Modelling and Turbulence Simulations. International Conference on Near-Wall Turbulent Flows, Tempe, Arizona, 1993, pp. 1031-1046.

17. Menter F.R. Two-Equation Eddy-Viscosity Turbulence Models for Engineering Applications. AIAA Journal, 1994, vol. 32, no. 8, pp. 1598-1605. DOI: 10.2514/3.12149

18. Menter F.R. Eddy Viscosity Transport Equations and their Relation to the $k-\varepsilon$ Model. ASME Journal of Fluids Engineering, 1997, vol. 119, no. 4, pp. 876-884. DOI: 10.1115/1.2819511

19. Menter F.R., Kuntz M., Langtry R. Ten Years of Industrial Experience with the SST Turbulence Model, Turbulence, Heat and Mass Transfer 4, Begell House, 2003, pp. 625-632.

20. Menter F.R. Review of the Shear-Stress Transport Turbulence Model Experience from an Industrial Perspective. International Journal of Computational Fluid Dynamics, 2009, vol. 23, no. 4, pp. 305-316. DOI: 10.1080/10618560902773387

21. Shih T.-H., Liou W.W., Shabbir A., Yang Z., Zhu J. A New $k-\varepsilon$ Eddy-Viscosity Model for High Reynolds Number Turbulent Flows - Model Development and Validation. Computers and Fluids, 1995, vol. 24, no. 3, pp. 227-238. DOI: 10.1016/0045-7930(94)00032-T

22. Behnia M., Parneix S., Shabany Y., Durbin P.A. Numerical Study of Turbulent Heat Transfer in Confined and Unconfined Impinging Jets. International Journal of Heat and Fluid Flow, 1999, vol. 20, no. 1, pp. 1-9. DOI: 10.1016/S0142-727X(98)10040-1

Received May 9, 2016

\section{МАТЕМАТИЧЕСКОЕ МОДЕЛИРОВАНИЕ ВИХРЕОБРАЗОВАНИЯ В ПРОТОЧНОЙ ЧАСТИ РАСХОДОМЕРА, ВЫБОР ОПТИМАЛЬНОЙ МОДЕЛИ ТУРБУЛЕНТНОСТИ}

\section{А.Л. Карташев, А.А. Кривоногов}

Статья посвящена математическому моделированию процессов, происходящих в проточной части вихревого расходомера при помощи конечно-элементных методов. Актуальность обусловлена недостатком информации по этому направлению на данный момент.

Проведен анализ современных источников информации по исследованию процессов нестационарного вихреобразования и других гидрогазодинамических эффектов в проточной части вихревого расходомера и подобных устройствах. Приведено краткое описание процесса вихреобразования за телом обтекания, расположенном в трубопроводе круглого сечения. Приведены основные критерии работоспособности изделия.

Рассмотрены различные математические модели для описания турбулентных течений в трубах с препятствием, проанализированы программные пакеты, на базе которых возможно моделирование нестационарных турбулентных течений. 
Проточная часть была смоделирована в программном комплексе ANSYS в модуле CFX для жидкости и газа, с применением различных подходов к математическому моделированию. В статье приводится краткое описание по основным настройкам расчетной области, по построению сетки и заданию начальных и граничных условий. Для верификации численных расчетов проводились физические эксперименты на проливочных установках и на газовом стенде. Для этого были изготовлены и протестированы образцы, соответствующие численным моделям.

По результатам исследований было установлено, что наиболее оптимальным подходом, с точки зрения точности и времени расчета, при численном моделировании процессов вихреобразования (дорожки Кармана) в вихревом расходомере является использование осредненной по Рейнольдсу системы уравнений Навье - Стокса, которая замыкается при помощи моделей турбулентности $k-\varepsilon$, что подтверждается сравнением с экспериментом.

Ключевые слова: математическое моделирование; вихревые расходомеры; модель турбулентности; тело обтекания; проточная часть.

\section{Литература}

1. Кремлевский, П.П. Расходомеры и счетчики количества / П.П. Кремлевский. - Л.: Машиностроение, 1989. - 701 с.

2. Baker, R.C. Flow Measurement Handbook / R.C. Baker. - N.-Y.: Cambridge University Press, 2000. $-524 \mathrm{p}$.

3. Кремлевский, П.П. Расходомеры и счетчики количества веществ. Кн. 1 / П.П. Кремлевский - СПб.: Политехника, 2002. - 409 с.

4. Карташев, А.Л. Исследование пространственных гидрогазодинамических эффектов в проточной части вихревого расходомера / А.Л. Карташев, А.А. Кривоногов // Вестник ЮУрГУ. Серия: Машиностроение. - 2015.- Т. 15, № 4. - С. 5-13. DOI: $10.14529 /$ engin150401

5. Фабер, Т.Е. Гидроаэродинамика / T.Е. Фабер. - М: Постмаркет, 2001. - 560 с.

6. Карташев, А.Л. Исследование пространственных гидродинамических эффектов в проточной части вихревого расходомера и оценка возможности их численного моделирования [Электронный ресурс] / А.Л. Карташев, А.А. Кривоногов // Наука ЮУрГУ. Секция технических наук. Материалы 66-й научной конференции, 2014. - С. 33-40. URL: http: // dspace.susu.ru/xmlui/bitstream/handle/0001.74/4287/3.pdf (дата обращения: 8.05.2016)

7. Использование численных методов моделирования при разработке вихревых расходомеров / В.Д. Богданов, А.В. Конюхов, А.А. Кривоногов, Е.В. Сафонов, В.А. Дорохов // Датчики и системы. - 2012. - № 8 (159). - С. 40-43.

8. Снегирев, А.Ю. Высокопроизводительные вычисления в технической физике. Численное моделирование турбулентных течений / А.Ю. Снегирев. - СПб.: Изд-во Политехн. ун-та, 2009. - 143 с.

9. Bailly, C. Turbulence / C.Bally, G. Comete-Bellot. - Springer International Publishing, 2015. - 360 p.

10. Spalart, P.R. Strategies for Turbulence Modelling and Simulations / P.R. Spalart // International Journal of Heat and Fluid Flow. - 2000. - V. 21. - P. 252-263.

11. Wilcox, D.C. Turbulence Modelling for CFD / D.C. Wilcox. - La Canada, California: DCW Industries Inc., 1998. - 477 p.

12. Spalart, P.R. A One-Equation Turbulence Model for Aerodynamic Flows / P.R. Spalart, S.R. Allmaras // Technical Report AIAA-92-0439. 30th Aerospace Scinces Meeting and Exibit, 1992. - 22 p. 
13. Launder, B.E. Lectures in Mathematical Models of Turbulence / B.E. Launder, D.B. Spalding. - London: Academic Press, 1972. - 169 p.

14. Лапин, Ю.В. Внутренние течения газовых смесей / Ю.В. Лапин, М.Х. Стрелец. - М.: Наука, 1989. - 368 c.

15. Pope, S.B. Turbulent Flows / S.B. Pope. - Cambridge: Cambridge Univ. Press, 2000 - 771 p.

16. Renormalization Group Modelling and Turbulence Simulations / S.A. Orszag, V. Yakhot, W.S. Flannery, F. Boysan, D. Choudhury, J. Maruzewski, B. Patel // International Conference on Near-Wall Turbulent Flows. - Tempe, Arizona, 1993. - P. 1031-1046.

17. Menter, F.R. Two-Equation Eddy-Viscosity Turbulence Models for Engineering Applications / F.R. Menter // AIAA Journal. - 1994.- V. 32, № 8. - P. 1598-1605.

18. Menter, F.R. Eddy Viscosity Transport Equations and their Relation to the Model F.R. Menter // ASME Journal of Fluids Engineering. - 1997. - V. 119, № 4. - P. 876-884.

19. Menter, F.R. Ten Years of Experience with the SST Turbulence Model / F.R. Menter, M. Kuntz, R. Langtry // Turbulence, Heat and Mass Transfer 4. - Begell House Inc. 2003. - P. 625-632.

20. Menter, F.R. Review of the Shear-Stress Transport Turbulence Model Experience from an Industrial Perspective / F.R. Menter // International Journal of Computational Fluid Dynamics. - 2009. - V. 23, № 4. - P. 305-316.

21. A New $k-\varepsilon$ Eddy-Viscosity Model for High Reynolds Number Turbulent Flows - Model Development and Validation / T.-H. Shih, W.W. Liou, A. Shabbir, Z. Yang, J. Zhu // Computers and Fluids. - 1995. - V. 24, № 3. - P. 227-238.

22. Numerical Study of Turbulent Heat Transfer in Confined and Unconfined Impinging Jets / M. Behnia, S. Parneix, Y. Shabany, P.A. Durbin // International Jounal of Heat and Fluid Flow. - 1999. - V. 20, № 1. - P. 1-9.

Александр Леонидович Карташев, доктор технических наук, профессор, кафедра «Летательные аппараты и автоматические установки», Южно-Уральский государственный университет (г. Челябинск, Российская Федерация), al_kartashev@mail.ru.

Алексей Александрович Кривоногов, аспирант, кафедра «Летательные аппараты и автоматические установки», Южно-Уральский государственный университет (г. Челябинск, Российская Федерация), alexeykrivonogov@mail.ru.

Поступила в редакцию 9 мая 2016 г. 